\title{
Genetic diversity in barley landraces (Hordeum vulgare L. subsp. vulgare) originated from Crescent Fertile region as detected by seed storage proteins
}

\author{
RIM MZID $^{1 *}$, FARHAT CHIBANI ${ }^{2}$, RAYDA BEN AYED $^{3}$, MOHSEN HANANA $^{1}$, JOELLE BREIDI $^{4}$, \\ RABIH KABALAN $^{4}$, SAMIH EL-HAJJ ${ }^{5}$, HASSAN MACHLAB ${ }^{6}$, AHMED REBAI $^{3}$ and LAMIS CHALAK ${ }^{5}$ \\ ${ }^{1}$ Laboratoire des Plantes Extrémophiles (LPE), Centre de Biotechnologie de Borj Cédria (CBBC), BP 901, \\ Hammam-lif 2050, Tunisie \\ ${ }^{2}$ Laboratoire de Physiologie Moléculaire des Plantes (LPMP), Centre de Biotechnologie de Borj Cédria (CBBC), BP 901, \\ Hammam-lif 2050, Tunisie \\ ${ }^{3}$ Molecular and Cellular Screening Processes Laboratory, Centre of Biotechnology of Sfax, PB 1177, 3018 Sfax, Tunisia \\ ${ }^{4}$ Department of Plant Breeding, Lebanese Agricultural Research Institute, P.O. Box 287, Zahlé, Lebanon \\ ${ }^{5}$ Department of Plant Production, Faculty of Agriculture, The Lebanese University, Dekwaneh, Beirut, Lebanon \\ ${ }^{6}$ International Centre for Agricultural Research in Dry Areas, Bachir Al-Kassar Street, P.O. Box 114/5055, Verdun, \\ Beirut, Lebanon
}

\begin{abstract}
[Mzid R., Chibani F., Ben Ayed R., Hanana M., Breidi J., Kabalan R., El-Haji S., Machlab H., Rebai A. and Chalak L. 2016 Genetic diversity in barley landraces (Hordeum vulgare L. subsp. vulgare) originated from Crescent Fertile region as detected by seed storage proteins. $J$. Genet. 95, 733-739]
\end{abstract}

\section{Introduction}

Barley is of renewed interest throughout the world because of its nutritional value and low glycemic index (Ullrich 2011). Lebanon belongs to the near east Crescent Fertile region which is considered as one of the most important centres of diversity in the world and where barley domestication started 10,000 years ago (Zohary and Hopf 1993). In recent years, the diversity in this region and the crop production are seriously threatened by the climate change and various anthropogenic pressures. Landraces are a useful source of genetic variability that offer an interesting tool to mitigate climatic change effects. However, little attention has been attributed to assess their variability and potential in breeding programmes. Thereafter, a thorough investigation of the existing variability will be of major importance for both evaluating and managing barely landraces. For these reasons, various tools have been used for studying barley genetic diversity. Phenological and morphological quantitative traits have been largely used, but these markers are not enough to verify genetic diversity in barley (Buck-Sorlin 2002; Hübner et al. 2013). In recent years, it has been suggested that

*For correspondence. E-mail: r_mzid@yahoo.fr.

Rim Mzid and Farhat Chibani contributed equally to this work. biochemical accomplished with molecular markers can be used to solve population diversity of barley.

Hordeins are the storage proteins of the wild and cultivated barleys. Numerous studies have reported (Eshghi et al. 2012; Hajmansoor et al. 2013; Rahimi et al. 2014) that it is possible to use hordeins for diversifying barley species because of its considerable variation. In fact, the hordeins can be divided into three main groups based on differences in size and sulphur content: sulphur-rich (B-hordeins and A-hordeins), sulphur-poor (C-hordeins) and high molecular weight (HMW, D-hordeins) (Shewry et al. 1995). B-hordeins and C-hordeins are the two major groups of polymeric storage proteins. B-hordeins are larger component with a fractions account for $70-80 \%$ of the total hordein in the barley endosperm than C-hordeins (10-12\%) (Molina-Cano et al. 2001). There is scarcely any research work carried on hordein polymorphism in near-east and north Africa. To the best of our knowledge, there is only one paper on hordein polymorphism for studying the genetic structure of Jordanian barley landraces in the literature (Baloch et al. 2014). The aim of this work was to explore the genetic diversity of Lebanese barley landraces (Hordeum vulgare L. subsp. vulgare) using biochemical markers as hordeins (loci Hord1 and Hord2) as a first step towards their further utilization in breeding programme in the near east region.

Keywords. landraces; genetic diversity; hordein polymorphism; storage proteins, Hordeum vulgare L. 


\section{Materials and methods}

\section{Samples collection}

Fifty-three Lebanese landraces of barley were used in this study including four sets of materials: (i) 35 landraces collected in 2011 from different agroclimatic areas in Lebanon (LR1-LR35); (ii) 15 landraces recovered from the GenBank of ICARDA-Aleppo and initially collected in the nineties from different agroclimatic areas in Lebanon (LR36-LR50); (iii) two improved barley varieties released by ICARDA (International Centre for Agricultural Research in the dry areas), namely Rihane-3 and Manel (6 rows); (iv) a sample of $H$. spontaneum widely growing in Lebanon. The geographical data of barley accessions under study are shown in figure 1 and table 1.

\section{Extraction of seed storage proteins}

For each landrace, five single seed progenies were analysed. Three seeds per landrace were skinned and crushed into a fine powder and then the endosperm storage proteins were extracted. The procedures of extraction were carried out in accordance with Doll and Andersen (1981).

\section{Sodium dodecyl sulphate polyacrylamide gel electrophoresis (SDS-PAGE)}

SDS-PAGE was performed to separate the extracted proteins by using $12 \%$ separating and 5\% stacking gels with a Mini Protean System from Bio-Rad according to Laemmli modified method (Laemmli 1970). In this study, we adopted constant current electrophoresis instead of constant voltage. The loading of sample was $15 \mu \mathrm{L}$. Starting current was $30 \mathrm{~mA}$, and then shifted to $50 \mathrm{~mA}$ when the bromophenol blue marker got to the borderline of stacking and separation gels. After electrophoresis, protein bands were stained for about $4 \mathrm{~h}$ overnight using staining solution: 12\% (w/v) trichloroacetic acid solution containing 5\% (v/v) ethanol and 0.05\% (w/v) Coomassie Brilliant Blue R-250 (Sigma), and

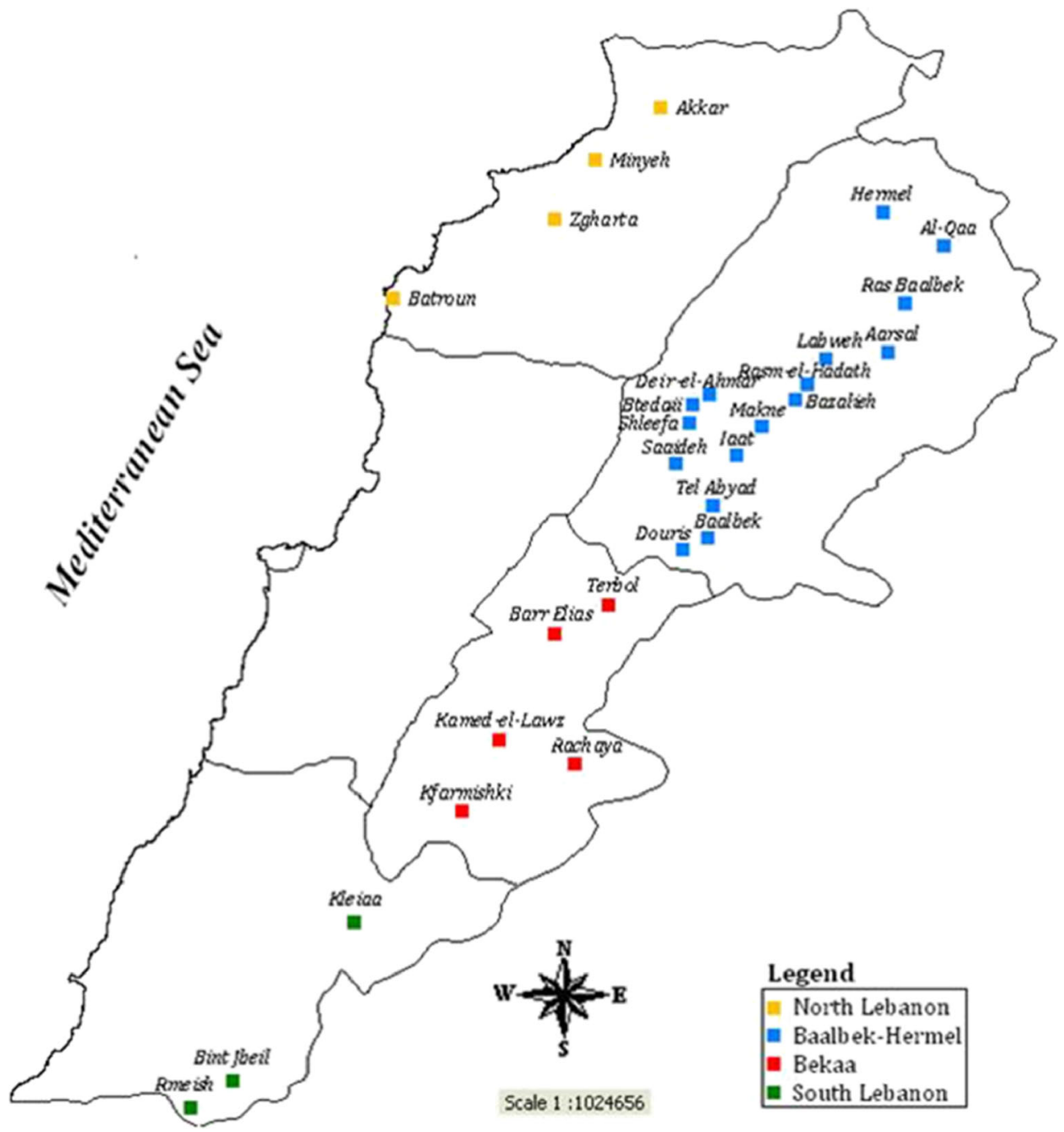

Figure 1. Collection site and geographic distribution of barley landraces collected in this study. Landraces presented in red colour are from Bekaa Caza; blue, Baalbek-Hermel; green, south Lebanon; dark yellow, north Lebanon. 
Table 1. Climatic and geographic distribution of the locations surveyed in Lebanon for collecting barley landraces.

\begin{tabular}{|c|c|c|c|c|c|c|c|}
\hline Caza & Location & Altitude (m) & Rainfall (mm) & $T_{\min } *\left({ }^{\circ} \mathrm{C}\right)$ & Latitude $\left({ }^{\circ} \mathrm{N}\right)$ & Longitude $\left({ }^{\circ} \mathrm{E}\right)$ & Landraces collected \\
\hline \multirow[t]{5}{*}{ Bekaa } & Terbol & 887 & 253.2 & -0.2 & 33.8181 & 35.9831 & LR1 $(6 \text { row })^{* *}$ \\
\hline & Kfarmishki & 1195 & 1089 & 3.38 & 33.5153 & 35.7667 & LR2 (2 row) \\
\hline & Kamed Lawz & 1222 & 847 & -0.06 & 33.6203 & 35.8214 & LR3 (6 row) \\
\hline & Barr Elias & 879 & 318 & -0.06 & 33.7747 & 35.9042 & LR4 (2 row), LR5 (6 row) \\
\hline & Rachaya & 1480 & 1123 & -5.72 & 33.5833 & 35.9333 & LR50 (2 row) \\
\hline \multirow[t]{3}{*}{$\begin{array}{l}\text { South } \\
\text { Lebanon }\end{array}$} & Bint Jbeil & 724 & 937.2 & 6.27 & 33.12 & 35.43 & $\begin{array}{c}\text { LR6 (6 row), LR7 (6 row), } \\
\text { LR8 (2 row) }\end{array}$ \\
\hline & Kleiaa & 714 & 1000 & 6.56 & 33.3311 & 35.6204 & LR9 (6 row) \\
\hline & Rmeish & 562 & 308 & 4.64 & 33.08 & 35.37 & LR10 (2 row), LR11 (6 row) \\
\hline \multirow[t]{16}{*}{ Baalbek-Hermel } & Deir-el-Ahmar & 986 & 1200 & -7 & 34.1253 & 36.1311 & LR12 (6 row) \\
\hline & Shleefa & 990 & 427 & -0.88 & 34.0853 & 36.1003 & LR13 (6 row) \\
\hline & Iaat & 1083 & 253 & 0 & 34.0369 & 36.1714 & LR14 (2 row) \\
\hline & Btedaii & 998 & 432 & -0.83 & 34.1122 & 36.1061 & LR15 (6 row) \\
\hline & Saaideh & 1018 & 185 & 0 & 34.0258 & 36.0817 & LR16 (6 row) \\
\hline & Douris & 1134 & 423.6 & -1.57 & 33.8978 & 36.0919 & LR17 (6 row), LR18 (2 row) \\
\hline & Bazalieh & 1041 & 350 & 0 & 34.1197 & 36.2584 & LR19 (2 row), LR20 (6 row) \\
\hline & Tel Abyad & 1025 & 423.6 & -1.57 & 33.95 & 36.15 & LR21 (2 row) \\
\hline & Makne & 1068 & 350 & -0.06 & 34.0797 & 36.2067 & LR22 (2 row) \\
\hline & Rasm Al-Hadath & 958 & 300 & 0 & 34.1414 & 36.2756 & LR23 (6 row) \\
\hline & Ras Baalbek & 1214 & 300 & -1.76 & 34.2589 & 36.4192 & $\begin{array}{c}\text { LR24 (2 row), LR25 (2 row), } \\
\text { LR26 (6 row) }\end{array}$ \\
\hline & Hermel & 696 & 208.4 & 1.19 & 34.3942 & 36.3847 & LR27 (6 row), LR28 (2 row) \\
\hline & Al-Qaa & 648 & 225.8 & 0.35 & 34.3442 & 36.4744 & $\begin{array}{l}\text { LR29 (2 row), LR30 (6 row), } \\
\text { LR31 (2 row), LR32 (6 row) }\end{array}$ \\
\hline & Aarsal & 1228 & 432 & -0.74 & 34.1886 & 36.3923 & LR33 (6 row), LR34 (2 row) \\
\hline & Labweh & 1007 & 350 & 0 & 34.1789 & 36.3021 & LR35 (2 row) \\
\hline & Baalbek & 1050 & 383.6 & -5.81 & 33.9333 & 36.1002 & $\begin{array}{c}\text { LR36 (2 row), LR37 (2 row), } \\
\text { LR38 ( } 2 \text { row) }\end{array}$ \\
\hline \multirow[t]{4}{*}{$\begin{array}{l}\text { North } \\
\text { Lebanon }\end{array}$} & Batroun & 150 & 900 & 6.78 & 34.2667 & 35.6667 & $\begin{array}{c}\text { LR39 (6 row), LR40 (6 row), } \\
\text { LR43 (6 row), LR48 (6 row), } \\
\text { LR49 (6 row) }\end{array}$ \\
\hline & Zgharta & 426 & 1148 & 6.17 & 34.440 & 35.903 & LR41 (6 row), LR42 (6 row) \\
\hline & Minyeh & 150 & 837.9 & 7.45 & 34.4333 & 36.05 & LR47 (6 row) \\
\hline & Akkar & 100 & 539.2 & 7.20 & 34.5258 & 36.0119 & $\begin{array}{c}\text { LR44 (6 row), LR45 (6 row), } \\
\text { LR46 (6 row) }\end{array}$ \\
\hline
\end{tabular}

* $T_{\min }$ is calculated from the average of the coldest month, **LR1-LR35, landraces collected in 2011 from different agroclimatic areas in Lebanon; LR36-LR50, landraces recovered from ICARDA GenBank (Aleppo) and initially collected in the nineties from different agroclimatic areas in Lebanon.

finally destained in solution containing $9 \%$ methanol and $2 \%$ acetic acid. Relative electrophoresis was performed at $4{ }^{\circ} \mathrm{C}$ until the blue marker reached the bottom of the gels. The gels were visualized by transilluminator and scanned by Bio-Rad versa DOC3000 gel imaging system. 'Broad range protein marker' was brought from BIOMATIK.

\section{Analysis of banding patterns}

Gels were photographed while identification and analysis of protein bands were performed by the software of Quantity one 4.5.1 (Bio-Rad). Molecular weight of protein bands were estimated by their relative mobility. Monomeric prolamins were classified as present (represented by 1) or absent (represented by 0 ) of all the examined bands. A data matrix was prepared for the analysis and their frequencies were calculated.

\section{Statistical analysis}

The data matrix was converted into a matrix of similarity $(S)$ values using Jaccard coefficient (Jaccard 1908). For a pair of two accessions, $i$ and $j$, this coefficient is calculated as:

$$
S_{i j}=\frac{n_{i j}}{n_{i j}+n_{i}+n_{j}},
$$

where $n_{i}$ is the number of bands present in accession $i$ and absent in accession $j, n_{j}$ is the number of bands present in $j$ and absent in $i$, and $n_{i j}$ is the number of bands shared by the two accessions $i$ and $j$.

A tree is then inferred using the unweighed pair group method by unweighed pair group method with arithmetic means (UPGMA) clustering algorithm and Jaccard similarity coefficients. All analyses were done using NTSys Pc program ver. 2.1 (Rohlf 1999). To find out the relation 
between the obtained linkage groups and parameters of row numbers, agroclimatic conditions and geographic origin, a chi-square test was conducted (Pearson 1897).

\section{Results and discussion}

\section{Polymorphism of hordein bands}

The SDS-PAGE is considered as a reliable technology, simple and mostly employed for identification of genetic diversity and analysis of genetic structure of germplasm. In this study, hordein polymorphism analysis was carried out with the SDS-PAGE method. The full compositions of storage proteins were separated by $12 \%$ separation gel and divided into four groups (A, B, C and D hordeins). The major part of hordeins $(80 \%)$ is formed by B-hordeins and C-hordeins, while A-hordeins are not considered to be a storage fraction and the D-hordeins are less variable than B-hordeins and Chordeins (Salcedo et al. 1980). Two zones, A and D, were not taken into account to make long migrations and obtain a better resolution for zones B and C. All possible bands of the slow moving Hor-1 and the fast migrating Hor-2 were identified. A total of 37 bands were observed ranging from 20 to $87 \mathrm{KDa}$. Electrophoresis of barley storage protein revealed 53 types of patterns with different electrophoresis motilities as shown in figure $2 \mathrm{a}$. This result indicated an important set of polymorphism. While examining the results of $\mathrm{C}$-hordeins for all accessions, 17 patterns $(\mathrm{C} 1-\mathrm{C} 17)$ and nine different bands ranged from $56-87 \mathrm{kDa}$ were observed, of which pattern C4 was the most common occurring in $19.16 \%$ of the accessions. The diagrammatic representation of hordein band patterns is illustrated in figure $2 \mathrm{~b}$. As of the Lebanese landraces, all bands were polymorphic, except one that was monomorphic and found in all accessions. In the zone B, 36 patterns (B1-B36) and 28 bands ranging from 20 to $53 \mathrm{kDa}$ were observed; the most common pattern was B3 which was found in three accessions, followed by B1 recorded in two accessions. The electrophoregram revealed a total of 37 bands and 53 different patterns among the studied accessions in areas B and $\mathrm{C}$ with an average number of bands of 12.28 and a maximum of 17 bands per landrace (figure 2b). Accessions designated as LR26 and LR16 as well as Manel and Rihane-3 varieties had the least number of eight bands, while accessions LR34 and LR19 had the maximum number of 17 bands.

These results are in line with those of Eshghi et al. (2012) obtained in naked barley accessions, where an average band number of 14.65 and 32 different patterns were found for Bhordeins and C-hordeins. Cooke (1995) reported up to 105 bands among 706 barley cultivars, while Sipahi et al. (2010) obtained 15 bands in 34 cultivars. Recently, Baloch et al. (2014) observed 20 hordein band patterns in 90 accessions collected from four different sites of Jordan. In fact, this large variability can be explained by the duplication and the divergence of an ancestral wild gene that generates a multigenic family (Shewry 1995). This later family provides additional opportunities for increasing polymorphism resulting from its neutral nature at evolution level and its high tolerance to mutations. One cause of this variability may be the linkage of the hordein loci to the Mla locus, which specifies the resistance to different races of powdery mildew (Oram et al. 1975).

\section{Genetic similarities and cluster analysis}

To elucidate the genetic relationships among the 53 barley accessions studied, a dendrogram was produced using UPGMA cluster analysis and Jaccard similarity coefficients based on the polymorphism data generated by B-hordeins and $\mathrm{C}$-hordeins. Four groups were differentiated at a distance of 0.66 (figure 3). Group 1 is the largest one, constituted of 27 landraces of different row numbers and various agroclimatic areas. The second group contains only nine landraces LR33, LR17, LR32, LR25, LR28, LR6, LR13, LR26 and LR18. The third group is formed by 14 landraces LR14, LR27, LR11, LR29, LR24, LR31, LR4, LR12, LR22, LR41, LR20, LR40, LR2, LR16, in addition to the wild $H$. spontaneum. Finally, the two commercial varieties, Manel and Rihane-3, are found as singleton groups. It is worth noting that landraces sampled from the different agroclimatic areas of Lebanon do not cluster separately. As to the chi-square test (table 2), the genetic variability revealed in this study was not correlated to the geographic origin of samples provenance $(P=0.095$; chisquare $=14.87)$ or to the landrace row numbers $(P=0.694$; chi-square $=1.45$ ).

According to the genetic relationships among the 53 accessions based on the B-hordein and C-hordein markers, the landraces were clustered into three different groups separately from the commercial varieties. In addition, landraces included in the third group are less domesticated than the other studied samples. Further, the accessions designated as LR45, LR46, LR39, LR5, LR35, LR49, LR50, LR47, LR38 and LR37 are genetically more divergent than the commercial varieties. However, the two landraces LR36 and LR3 are very similar $(\mathrm{GS}=1)$. This later result can therefore be explained by two assumptions; LR36 and LR3 accessions are identical, but they are duplicated under two different designations, or these two landraces have a common ancestor that is very close in the time.

Lebanon is a small country where seeds are easily exchanged between farmers' communities in the different parts of the country. This may explain the absence of correlation between the genetic variability and the geographic origin of sample provenance as shown in the clustering of landraces. Similar results were previously reported for barley landraces growing in Jordan (Baloch et al. 2014). According to Nevo (1998), gene flow is expected in the Fertile Crescent region since populations of cultivated barley have long been growing in close proximity. Similar results were previously reported by Atanassov et al. (2001). Contrarily, Rahimi et al. (2014) pointed out the relation between the polymorphism of storage proteins and geographical provenances of barley accessions. It is worthy to note that such correlation is 


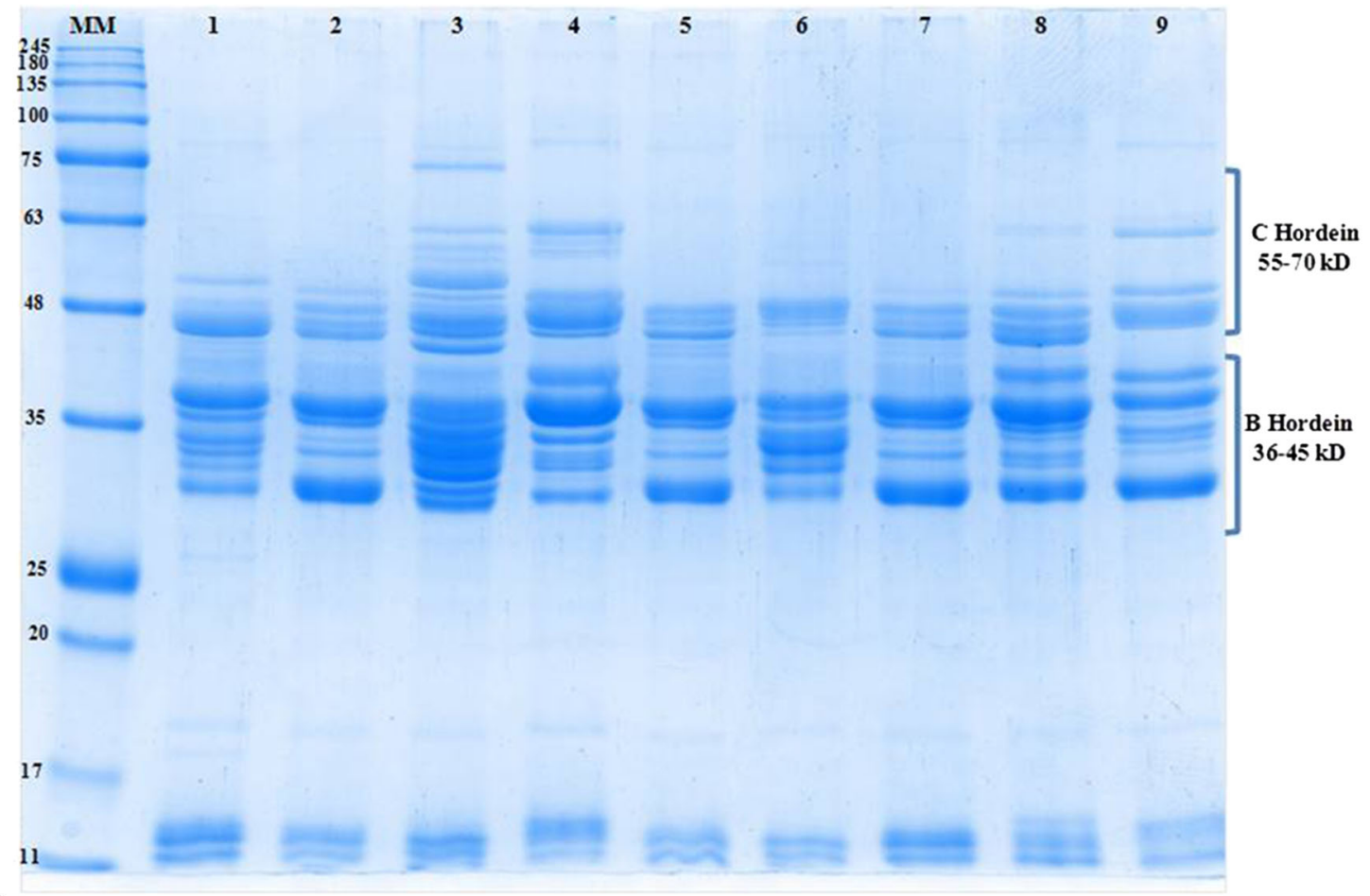

(a)

C hordeins

$\frac{1}{2} \frac{2}{3}+\frac{4}{5} \frac{5}{6} \frac{7}{8} \frac{9}{10} \frac{11}{12} \frac{13}{14} \frac{15}{1} 16 \quad 17$

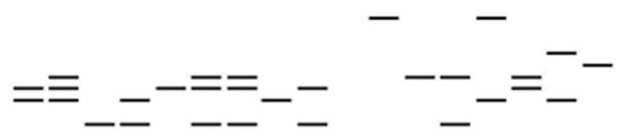

B hordeins

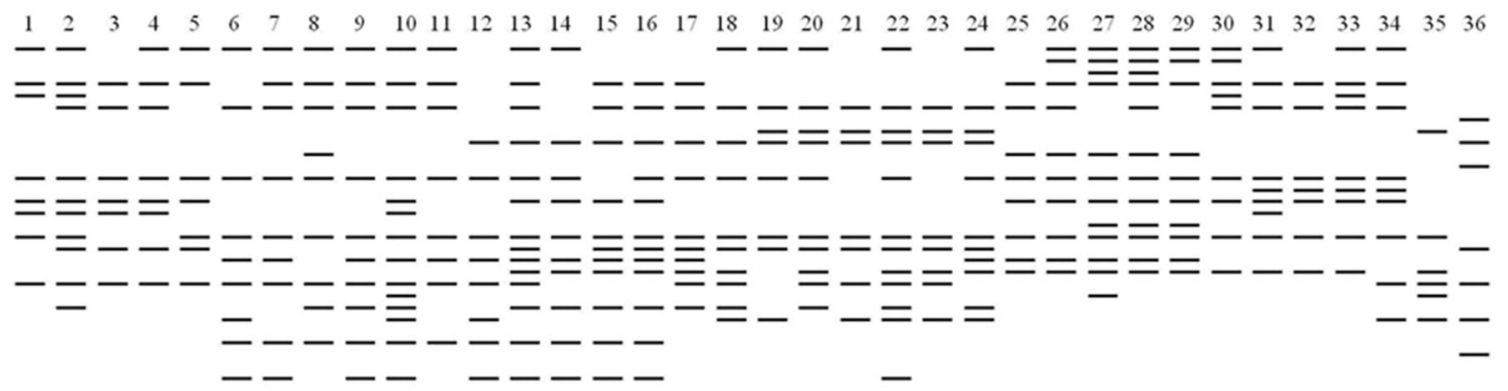

(b)

Figure 2. SDS-PAGE analysis of B- and C-hordein proteins in different barley landraces. (a) Electrophoretic profile of some barley landraces separated by SDS-electrophoresis from single seeds. PM indicates protein molecular weight marker 'broad range protein marker' from Biomatik. (1), (2), (3), (4), (5), (6), (7), (8) and (9) represent different barley landraces. (b) Diagrammatic representation of all SDS-PAGE patterns of B-hordein and C-hordein observed in the materiel study. The thickness of the line represents the most common intensity of the band of each accession.

strongly influenced by the number of samples considered in the study.

In conclusion, our paper provided the first assessment of genetic diversity for a set of 50 Lebanese barley landraces in comparison to the wild Hordeum spontaneum and two commercial varieties. Although preliminary, the clustering of landraces described here is of high priority to be used through appropriate breeding methods. Our findings confirm the effectiveness of hordein markers in studying the polymorphism and assessing the phylogenetic relationship among accessions collected from various agroclimatic areas. Nevertheless, this technique remains limited by the low number of seed storage protein markers in any particular species that may generate an insufficient polymorphism 


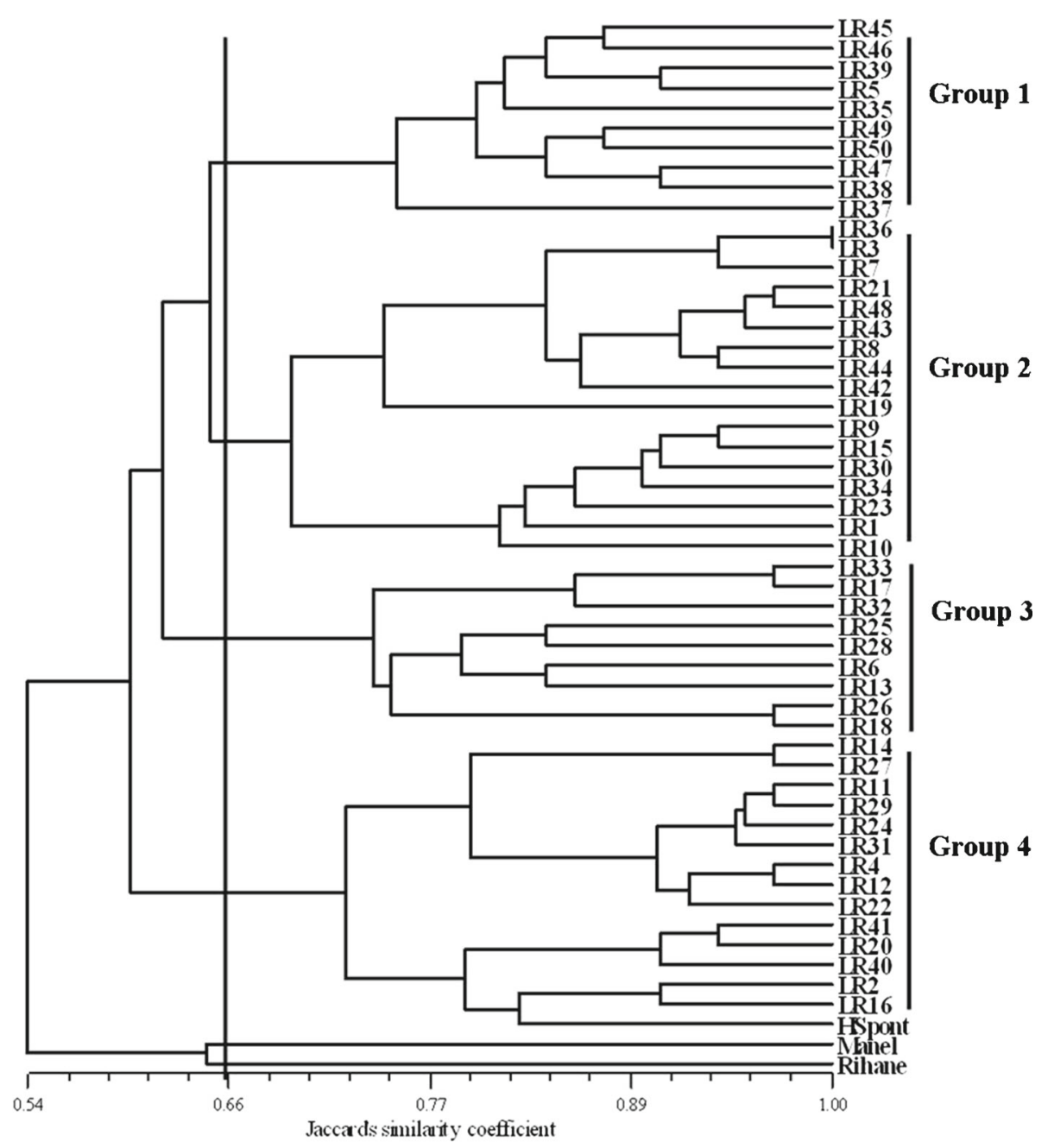

Figure 3. Dendrogram of 53 barely accessions generated by unweighed pair group method using an arithmetic average cluster analysis using Jaccard similarity coefficients from B-hordein and $\mathrm{C}$-hordein protein markers.

Table 2. Probability value for a chi-square test from four barely linkage groups.

\begin{tabular}{lcccc}
\hline & Rows number $(2$ or 6$)$ & Region* $^{*}$ & Altitude $^{* *}$ & Rainfall $^{* *}$ \\
\hline Chi-square & 1.45 & 15.70 & 4.63 & 19.36 \\
$P$ value & 0.694 & 0.073 & 0.592 & 0.022 \\
\hline
\end{tabular}

* All studied landraces were selected from four Lebanon regions (Bekaa, south, Balbek and north), see table 1 for more details.

** Based on the data in table 1 and the box plot performed by SPSS software, the altitude and rainfall were classified into three and four groups, respectively.

among closely-related genotypes (Bonfitto et al. 1999). For this reason, this first evaluation of barley genetic resources in Lebanon should be further completed by a DNA-based markers analysis such as microsatellites.

\section{Acknowledgements}

We gratefully thank Mrs Sana Louati for proofreading the present paper. This project is funded by the Grant Research Program-2011, National Council for Scientific Research, Lebanon (Ref. 3420). We are also grateful to Bariaa Hamadeh from Lari, Lebanon for her valuable support.

\section{References}

Atanassov P., Borries C., Zaharieva M. and Monneveux P. 2001 Hordein polymorphism and variation of agromorphological traits in a collection of naked barley. Genet. Resour. Crop Evol. 48, 353-360. 
Baloch A. W., Ali M., Baloch A. M., Mangan B. U. N. and Song W. 2014 Genetic diversity and structure analysis based on hordein protein polymorphism in barley landrace populations from Jordan. Pak. J. Bot. 46, 1397-1402.

Bonfitto R., Galleschi L., Macchia M., Saviozzi F. and Navari-Izzo F. 1999 Identification of melon cultivars by gel and capillary electrophoresis. Seed Sci. Technol. 27, 779-783.

Buck-Sorlin G. H. 2002 The search for QTL in barley (Hordeum vulgare L.) using a new mapping population. Cell Mol. Biol. Lett. 7, 523-535.

Cooke R. J. 1995 Distribution and diversity of hordein alleles in barley varieties. Seed Sci. Technol. 23, 865-871.

Doll H. and Andersen B. 1981 Preparation of barley storage protein, hordein, for analytical sodium dodecyl sulfate-polyacrylamide gel electrophoresis. Anal. Biochem. 115, 61-66.

Eshghi R., Abrahimpour F., Ojaghi J., Salayeva S., Sadigov H., Akhundova E. et al. 2012 Genetic structure and geographical differentiation in barley landraces based on storage proteins. Intl. J. Agri. Crop. Sci. 4, 960-970.

Hajmansoor S., Bihamta M. R. and Alisoltani A. 2013 Genetic diversity among and within Iranian and non-Iranian barely (Hordeum vulgare L.) genotypes using SSR and storage proteins markers. Biochem. Syst. Ecol. 46, 7-17.

Hübner S., Bdolach E., Ein-Gedy S., Schmid K. J., Korol A. and Fridman E. 2013 Phenotypic landscapes: phenological patterns in wild and cultivated barley. J. Evol. Biol. 26, 163-174.

Jaccard P. 1908 Nouvelles recherches sur la distribution florale. Bull. Soc. Vaud. Sci. Nat. 44, 223-270.

Laemmli U. K. 1970 Cleavage of structural protein during the assembly of the head of bacteriophage T4. Nature 227, 680-685.

Molina-Cano J. L., Polo J. P., Romera E., Araus J. L., Zarko J. and Swansto J. S. 2001 Relationship between barley hordeins and malting quality in a mutant of cv. Triumph I. Genotype by environment interaction of hordein content. J. Cereal Sci. 34, 285-294.
Nevo E. 1998 Genetic diversity in wild cereals: regional and local studies and their bearing on conservation ex situ and in situ. Genet. Resour. Crop. Evol. 45, 355-370.

Oram R. N., Dolí H. and Koie B. 1975 Genetics of two storage protein variants in barley. Hereditas 80, 53-58.

Pearson K. 1897 The German passion-play: a study in the evolution of western Christianity. In The chances of death and other studies in evolution (ed. Edward Arnold), Vol. 2, pp. 246-406. London and New York.

Rahimi M., Majidi Harvan I., Valizadeh M., Darvish Kajori F. and Ebrahimpour F. 2014 Evaluation of genetic diversity of wild-type barley Hordeum vulgare L. sub sp. spontaneum based on storage proteins polymorphism. Int. J. Biosci. 5, 266-274.

Rohlf F. J. 1999 NTsys-PC: numerical taxonomy and multivariate analysis system, version 2.1. Exeter Software, Setauket, New York, USA.

Salcedo G., Sanchez-Monge R., Argamenteria A. and Aragonsillo C. 1980 The A-hordeins as a group of salt soluble hydrophobic proteins. Plant Sci. Lett. 19, 109-119.

Shewry P. R., Tatham A. S., Barro F., Barcelo P. and Lazzeri P. 1995 Biotechnology of bread making: unravelling and manipulating the multi-protein gluten complex. Biotechnology 13, 1185-1190.

Shewry P. R. 1995 Plant storage proteins. Biol. Rev. Camb. Philos. Soc. 70, 375-426.

Sipahi H., Akar T., Yildiz M. A. and Sayim I. 2010 Determination of genetic variation and relationship in turkish barley cultivars by hordein and RAPD markers. Turk. J. Field Crop. 15, 108-113.

Ullrich S. E. 2011 Significance, adaptation, production, and trade of barley. In Barley: production, improvement, and uses, 1st edition (ed. S. E. Ullrich), pp. 3-13. Wiley-Blackwell, Oxford, UK.

Zohary D. and Hopf M. 1993 Domestication of plants in the old world. In The origin and spread of cultivated plants in West Asia, Europe, and the Nile Valley, 2nd edition. Clarendon Press, Oxford, U.K. 